\title{
A reappraisal of the diversity and class distribution of aspartate transcarbamoylases in Gram-negative bacteria
}

\author{
Martin J. Kenny, Donald McPhail and Margaret Shepherdson
}

Author for correspondence: Margaret Shepherdson. Tel: +44117965 6261. Fax: +44 1179763871.
e-mail: m-shepherdson@uwe.ac.uk

Department of Biological Sciences, University of the West of England, Frenchay Campus, Coldharbour Lane, Bristol BS16 1QY, UK

\begin{abstract}
Recently, the subunit composition of class A aspartate transcarbamoylases (ATCases) in fluorescent pseudomonads has been clarified. We present evidence that distribution of this type of ATCase may be more widespread than at first suspected. Bacterial ATCases exist in three forms: class A (molecular mass 450-500 kDa); class B, typified by Escherichia coli ATCase ( $\sim 300 \mathrm{kDa})$; and class C, typified by Bacillus subtilis ATCase ( $\sim 100 \mathrm{kDa})$. Using gradient gel electrophoresis with activity-staining to scan bacterial sonicates, we report the existence of six more class A ATCases. We have purified one of these, Acinetobacter calcoaceticus ATCase, and found its subunit composition to be similar to that of the pseudomonad ATCases. Two of these ATCases come from bacteria outside the $\gamma$-subgroup of the Proteobacteria, one from the $\alpha$-subgroup and one from Deinococcus radiophilus, a species phylogenetically remote from the Proteobacteria. Unexpectedly, three bacterial species, closely related to the fluorescent pseudomonads and acinetobacters, have ATCases of $100 \mathrm{kDa}$ (class C). One of these, Stenotrophomonas (formerly Xanthomonas) maltophilia has been purified and found to be a homotrimer of $35 \mathrm{kDa}$ polypeptide chains. We believe this is the first time that class C ATCases have been reported in Gram-negative bacteria. A distinctive cluster in the $\gamma=3$ subgroup of the Proteobacteria is formed by the enteric bacteria and their relatives. So far only class B ATCases have been reported in this group. The evolutionary implications of these findings are discussed.
\end{abstract}

Keywords: aspartate transcarbamoylase, molecular evolution, phylogeny

\section{INTRODUCTION}

The enzyme aspartate transcarbamoylase (ATCase; EC 2.1.3.2), which catalyses the first step unique to pyrimidine synthesis exists in a number of forms. The core catalytic component of all bacterial ATCases, however, is a homotrimer of approximately $34 \mathrm{kDa}$ polypeptides. This arrangement has been shown in Escherichia coli (Ke et al., 1984) and Bacillus subtilis (Brabson \& Switzer, 1975), and is a consequence of the active site being shared between adjacent polypeptides (Robey \& Schachman, 1985).

The most obvious feature of diversity in the bacterial ATCases is molecular size, which varies depending on whether or not the catalytic subunit is associated with other non-catalytic subunits, and the nature of these subunits. The earliest classification, by Bethell \& Jones

Abbreviation: ATCase, aspartate transcarbamoylase.
(1969), proposed three classes of bacterial ATCase on the basis of size.

Class A ATCases are the largest and are found in the fluorescent pseudomonads. Recently, three of these enzymes have been purified (Bergh \& Evans, 1993; Shepherdson \& McPhail, 1993; Schurr et al., 1995) and shown to have molecular masses in the region of $480 \mathrm{kDa}$. In addition to the $34 \mathrm{kDa}$ polypeptide chains of the catalytic subunit, the molecules contain polypeptide chains of around $45 \mathrm{kDa}$. It is proposed that the $34 \mathrm{kDa}$ chains form two catalytic trimers which associate with six of the larger chains. Dissociation of the enzyme into its separate subunits under conditions which retain activity has not been achieved (Bergh \& Evans, 1993; Shepherdson \& McPhail, 1993). It is not clear what function the $45 \mathrm{kDa}$ chains serve, but derived amino acid sequence comparisons suggest that this polypeptide is a nonfunctional homologue of the next enzyme in the pathway, dihydroorotase (Schurr et al., 1995). 
Class B ATCases include those from the enteric bacteria of which the ATCase from $E$. coli has been extensively studied; the molecule has two catalytic trimers and three homodimers of $17 \mathrm{kDa}$ chains which mediate very precise allosteric regulation of activity by binding nucleotides (reviewed by Kantrowitz \& Lipscomb, 1990). The molecular mass of ATCases in this group is approximately $300 \mathrm{kDa}$. Dissociation of these ATCases into catalytic trimers and regulatory dimers with retention of enzyme activity is relatively easy (Gerhart \& Holoubek, 1967).

Class C ATCases are exemplified by Bacillus subtilis ATCase which consists of a catalytic trimer alone (Brabson \& Switzer, 1975). All Gram-positive bacterial ATCases thus far examined have a molecular mass in the region of $100 \mathrm{kDa}$ (Switzer \& Quinn, 1993).

We have surveyed ATCases from 28 bacterial species, 12 of which have not been previously investigated and are reported here for the first time. We have classified them according to size. Most of the bacteria we have studied fall into the $\gamma-3$ subdivision of the Proteobacteria described by Woese (1987), and two are outside this group. We report the first purification of a class A ATCase which does not belong to the fluorescent pseudomonads, and a class $C$ ATCase from a Gram-negative organism. On the basis of our findings, we suggest that class A ATCases are far more widely distributed than has been previously thought and propose that this structure may be the dominant form of ATCase in Gram-negative bacteria.

\section{METHODS}

Bacterial strains. Unless otherwise stated, the organisms were obtained from the National Collection of Industrial and Marine Bacteria (NCIMB; identification numbers are given in parentheses): Xantbomonas campestris (11803), Stenotrophomonas (previously Xanthomonas) maltophilia (9203), Acinetobacter calcoaceticus (11826), Lysobacter enzymogenes (9924), Pseudomonas syringae pv. pisi (race 7 isolate no.1691 kindly provided by A. Vivian, this laboratory), Azomonas agilis (11693), Azotobacter vinelandii (12096), Leucotbrix mucor (2222), Escherichia coli DH5 $\alpha$ (13174), Vibrio natriegens (857), Paracoccus denitrificans (11627) and Deinococcus radiopbilus (10648).

Culture conditions and preparation of extracts. All bacteria were grown to mid-exponential phase using culture conditions suggested in the NCIMB Catalogue of Strains. When sonicates were prepared, the cells were harvested by centrifugation, resuspended in Tris/ $\mathrm{HCl}$ buffer $(50 \mathrm{mM}, \mathrm{pH} 7.5)$ containing EDTA $(1 \mathrm{mM})$ and dithiothreitol $(1 \mathrm{mM})$, then disrupted with an MSE sonicator using a $6 \mathrm{~mm}$ diameter probe $(4 \times 30 \mathrm{~s}$ bursts with cooling in ice water between bursts). Sonicates were centrifuged for $2 \mathrm{~h}$ at $20000 \mathrm{~g}$. On one occasion, $20 \%$ (w/v) PEG and $1 \mathrm{mM} \mathrm{ZnCl}$ were included in the disruption medium of $S$. maltophilia cells, in an attempt to prevent possible subunit dissociation of the ATCase taking place.

Enzyme assay. ATCase activity was determined by measuring the amount of inorganic phosphate produced in the reaction, under conditions which minimize the spontaneous breakdown of carbamoyl phosphate, as described by Shepherdson \& McPhail (1993). One unit of enzyme activity is defined as the amount of enzyme which catalyses the formation of $1 \mu \mathrm{mol}$ phosphate in $1 \mathrm{~min}$. Protein was assayed by the method of Bradford (1976).
SDSPAGE. In all cases, mini-slab gels (Atto Corporation) were used. The buffering conditions and gel composition were as described by Laemmli (1970).

Gradient electrophoresis under non-denaturing conditions. Precast 4-20\% (w/v) non-denaturing polyacrylamide gradient gels (Novex) were used to compare the size of ATCases present in different bacterial sonicates. Sonicates were suitably diluted with sample buffer so that the $10 \mu \mathrm{l}$ aliquots applied to each lane contained 0.01 units of ATCase activity. A mixture of molecular mass markers (Pharmacia, High Molecular Weight markers for electrophoresis under non-denaturing conditions) were run on the same gel. The buffering system was based on that described by Laemmli (1970) for SDS-PAGE except for the omission of SDS and reducing agent. Electrophoresis was carried out at $4{ }^{\circ} \mathrm{C}$ at a constant voltage of $125 \mathrm{~V}$ for $12 \mathrm{~h}$. After the run the gels were activity-stained for ATCase (Grayson et al., 1979).

Gel filtration. A Pharmacia Hiload Superdex 16/60 column was used to determine the molecular mass of ATCase in sonicates. The column was loaded with $0.5 \mathrm{ml}$ of sonicate containing approximately 5 units ATCase $\mathrm{ml}^{-1}$. The eluting buffer was Tris $/ \mathrm{HCl}(50 \mathrm{mM}, \mathrm{pH} 7 \cdot 5)$ containing $\mathrm{NaCl}(0 \cdot 1 \mathrm{M})$. The column was calibrated with thyroglobulin $(666 \mathrm{kDa})$, apoferritin $(440 \mathrm{kDa}), E$. coli ATCase $(310 \mathrm{kDa})$, catalase $(250 \mathrm{kDa})$, glucose-6-phosphate dehydrogenase $(150 \mathrm{kDa})$ and hexokinase $(100 \mathrm{kDa})$.

Purification of Ac. calcoaceticus and S. maltophilia ATCases. In both cases the growth conditions, harvesting and sonication of the cells were the same. Cells were grown at $30^{\circ} \mathrm{C}$ in Nutrient Broth (Oxoid) in 11 conical flasks containing $350 \mathrm{ml}$ medium. Each flask was inoculated with an overnight culture $(50 \mathrm{ml})$. The cells were harvested at mid-exponential phase (after about $6 \mathrm{~h}$ ). Sonication and centrifugation were performed as described above.

S. maltophilia. Solid ammonium sulphate was added to the supernatant (slowly, with stirring, at room temperature). The pellet obtained after centrifugation of the 45-65\% saturated fraction was collected; the pellet was stored overnight at $4{ }^{\circ} \mathrm{C}$. Subsequently, the pellet was dissolved in Tris $/ \mathrm{HCl}(20 \mathrm{mM}, \mathrm{pH}$ 7.5) and adjusted to an ammonium sulphate concentration of $1.7 \mathrm{M}$ before chromatography on a Pharmacia Phenyl Sepharose column (HR 5/5) using a linear gradient over the range $1.7-0.0 \mathrm{M}$ ammonium sulphate in Tris $/ \mathrm{HCl}(0.1 \mathrm{M}, \mathrm{pH} 7.5)$ over $30 \mathrm{ml}$. Active fractions from the column were desalted (Pharmacia Fast Desalting column HR 10/10) and rechromatographed on a Pharmacia Mono Q column which was eluted with a linear salt gradient over the range $0-1 \mathrm{M} \mathrm{NaCl}$ in Tris/ $\mathrm{HCl}$ $(20 \mathrm{mM}, \mathrm{pH} 8.5)$ over $40 \mathrm{ml}$. Active fractions were separately desalted, concentrated (Microcon 10, Amicon) and electrophoresed on a $7 \cdot 5 \%$ polyacrylamide gel with a $4 \%$ stacking gel under non-denaturing conditions. The gel was first stained for ATCase activity and the opalescent white bands nicked with a blade before staining the gel with Coomassie Blue. The fraction showing no protein contaminants in the region of the enzyme was electrophoresed once more under non-denaturing conditions after loading into a single lane running across the width of the gel. After activity staining, the white band was excised, and the protein electroeluted from the gel fragments (Biotrap, Schleicher \& Schuell). After concentration, the eluate was electrophoresed by SDS-PAGE using a $15 \%$ gel and a $4 \%$ stacking gel and stained with Coomassie Blue.

Ac. calcoaceticus. The sonicate was diluted 1:1 with deionized water and applied to a Pharmacia Mono $Q$ column in $2 \mathrm{ml}$ aliquots (approx. $25 \mathrm{mg}$ protein). Column elution was achieved with a linear gradient over the range $0-1 \mathrm{M} \mathrm{NaCl}$ in Bis Tris 
Propane $(20 \mathrm{mM}, \mathrm{pH} 8 \cdot 0)$. Active fractions were pooled and dialysed overnight at $4{ }^{\circ} \mathrm{C}$ against $1.7 \mathrm{M}$ ammonium sulphate, $50 \mathrm{mM}$ Tris/ $\mathrm{HCl}, 1 \mathrm{mM}$ dithiothreitol, adjusted to $\mathrm{pH} 7 \cdot 4$. The dialysate was rechromatographed on a Pharmacia Phenyl Sepharose column (HR5/5) eluted with a linear gradient over the range $1.7-0.0 \mathrm{M}$ ammonium sulphate. Buffering and additives were as described for the dialysing medium. Active fractions from the column were pooled and concentrated to $0.5 \mathrm{ml}$ by centrifugal concentration (Microcon 10, Amicon). The concentrate was applied to a gel filtration column (Hiload Superdex 16/60, Pharmacia) equilibrated with $50 \mathrm{mM}$ Tris/ $\mathrm{HCl}, 0 \cdot 1 \mathrm{M} \mathrm{NaCl}, 0 \cdot 05 \%$ sodium azide, $\mathrm{pH} 7 \cdot 4$. Active fractions were concentrated and analysed by PAGE carried out under non-denaturing conditions as described above. The gels were stained for A TCase activity and for protein as above. Fractions in which only one band was present which stained for both protein and enzyme activity were assessed by SDS-PAGE.

Chemicals. Chemicals were purchased from Sigma unless otherwise stated.

\section{RESULTS}

\section{Estimation of molecular mass of ATCases by PAGE on gradient gels under non-denaturing conditions}

Pretreated sonicates were electrophoresed for $12 \mathrm{~h}$ at $125 \mathrm{~V}$. After this time, there was no further migration as each molecular species had reached its limiting pore size in the gel (Arcus, 1970). The opaque white bands which appeared after activity staining the gels for ATCase are shown in Fig. 1. The ATCases fall into three migration groups which correspond approximately to $100 \mathrm{kDa}:(X$. campestris, S. maltophilia and Lys. enzymogenes), $300 \mathrm{kDa}$ (E. coli) and $450-500 \mathrm{kDa}$ (Ac. calcoaceticus, Leu. mucor, Azomonas agilis, Azotobacter vinelandii, D. radiophilus, $P$ s. syringae and Para. denitrificans).

Two activity staining bands were always visible on the gel from the Azomonas agilis (lane 8) and D. radiopbilus (lane 6)

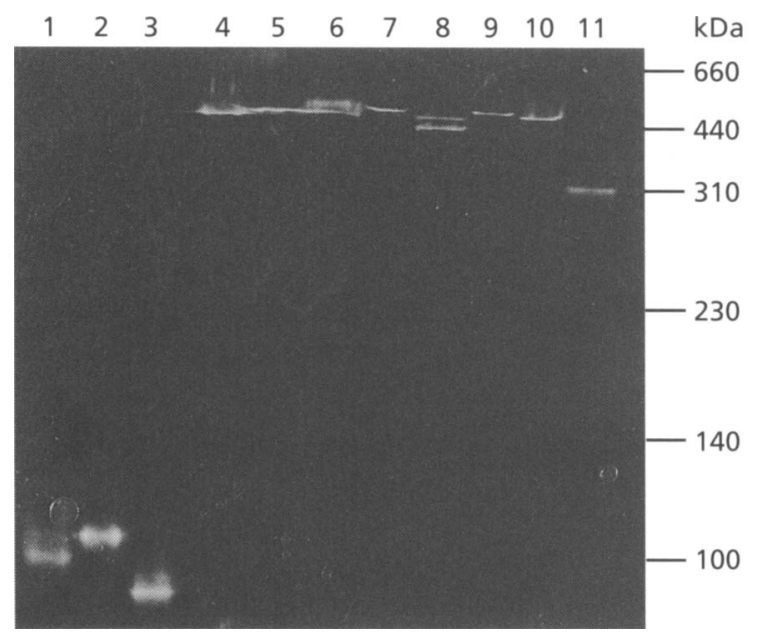

Fig. 1. PAGE of bacterial sonicates under non-denaturing conditions on 4-20\% gradient gels. Lanes: $1, X$. campestris; 2 , S. maltophilia; 3, Lys. enzymogenes; 4, Para. denitrificans; 5, Ps. syringae; 6, D. radiophilus; 7, Azotobacter vinelandii; 8, Azomonas agilis; 9, Leu. mucor; 10, Ac. calcoaceticus; 11, E. coli.
Table 1. Estimation of molecular mass by gel filtration

See Methods for details of procedure.

\begin{tabular}{|lc|}
\hline Organism & $\begin{array}{c}\text { Molecular } \\
\text { mass (kDa) }\end{array}$ \\
\hline V. natriegens & 280 \\
D. radiophilus & 500 \\
Ac. calcoaceticus & 480 \\
Ps. syringae & 490 \\
Lys. enzymogenes & 120 \\
S. maltophilia & 112 \\
X. campestris & 126 \\
\hline
\end{tabular}

extracts. No explanation can be offered for this but they appear to be due to genuine ATCase activity, since there were no bands on the control gel where aspartate was omitted from the activity stain. The ATCase from $V$. natriegens falls into the same molecular mass band as E. coli, but was not included on the gel in Fig. 1 because it stained much more slowly than the other enzymes. The relationship between molecular mass and migration distance departs from strict linearity below $140 \mathrm{kDa}$, which means obtaining an accurate estimate of molecular mass for proteins is not possible in this region of the gel.

The sonicate from $S$. maltophilia cells which had been extracted in the presence of $20 \% \mathrm{PEG}$ and $1 \mathrm{mM} \mathrm{ZnCl}$ was electrophoresed and treated as described. After activity staining, the apparent molecular mass of the enzyme was unchanged.

At least three separate batches of each species were cultured and analysed.

\section{Estimation of molecular mass of ATCases by gel filtration}

To confirm some of the results obtained from the gradient gels, molecular mass determinations were carried out by gel filtration. The results are shown in Table 1. The estimates obtained from gel filtration agreed with the molecular mass banding pattern shown on the gradient gels. The error of the gel filtration procedure was assessed at approximately $\pm 5 \%$, so it is not possible to attribute significant differences to molecular mass values of ATCases in the region of $100 \mathrm{kDa}$.

\section{Purification of the ATCases from S. maltophilia and Ac. calcoaceticus}

The purification procedures for both enzymes were performed on at least three occasions.

S. maltophilia. It would be reasonable to assume that the ATCases found to have a molecular mass value in the region of $100 \mathrm{kDa}$ would have the structure of the basic catalytic trimer as shown for the Gram-positive organism Bacillus subtilis (Brabson \& Switzer, 1975). To test this assumption, the ATCase from S. maltophilia was purified (the stages in the purification are described in Table 2). The overall purification after the chromatographic steps 
Table 2. Purification of ATCase from S. maltophilia

\begin{tabular}{|lcccc|}
\hline Step & $\begin{array}{c}\text { Total } \\
\text { activity } \\
\text { (units) }\end{array}$ & $\begin{array}{c}\text { Specific } \\
\text { activity } \\
\text { [units } \\
\text { (mg } \\
\text { protein) }\end{array}$ & $\begin{array}{c}\text { Purification } \\
\text { factor } \\
\text { (-fold) }\end{array}$ & $\begin{array}{c}\text { Yield } \\
\text { (\%) }\end{array}$ \\
\hline $\begin{array}{l}\text { 1. Sonicate* } \\
\text { 2. 45-65\% ammonium } \\
\text { sulphate pellet }\end{array}$ & 321 & $0 \cdot 26$ & 1 & 100 \\
$\begin{array}{l}\text { 3. Hydrophobic interaction } \\
\text { chromatography (Phenyl } \\
\text { Sepharose) }\end{array}$ & 194 & $1 \cdot 1$ & 4 & 60 \\
$\begin{array}{l}\text { 4. Anion exchange (Mono } \\
\text { Q) (most active fraction) }\end{array}$ & 6.8 & 83 & $13 \cdot 2$ & 37 \\
\hline
\end{tabular}

* Prepared from 61 of culture.

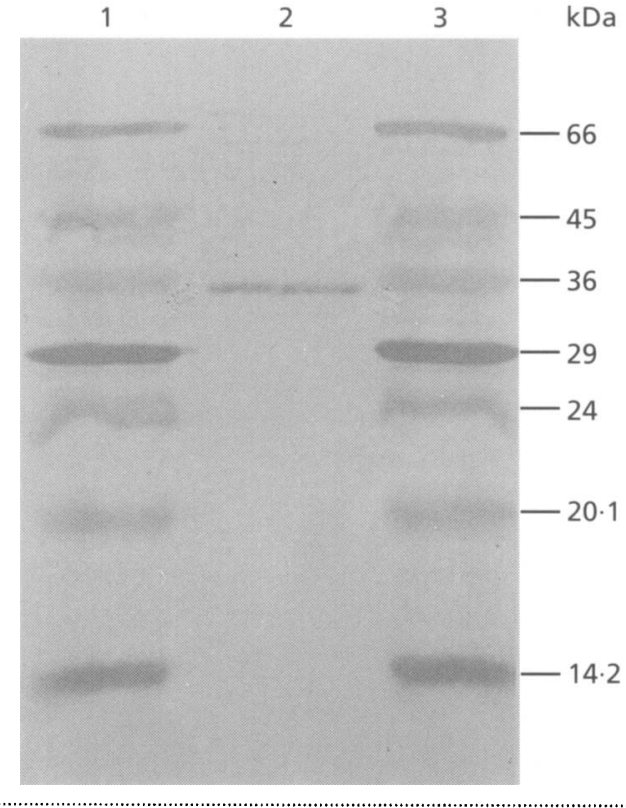

Fig. 2. SDS-PAGE of aspartate transcarbamoylase from $S$. maltophilia (lane 2). Lanes 1 and 3 are molecular mass markers.

was 320 -fold. At this stage PAGE under non-denaturing conditions, followed by activity staining and then by protein staining, showed that the enzyme constituted about one-third of the total protein in the sample (not shown). Excision and elution of the gel strip containing the enzyme activity, followed by SDS-PAGE gave a single band corresponding to $35 \mathrm{kDa}$ (Fig. 2). This information taken together with an estimated molecular mass of $112 \mathrm{kDa}$ suggests a trimeric structure for the enzyme.

A. calcoaceticus. The reasons for purifying this enzyme were similar. It has been shown that three fluorescent pseudomonads have ATCases with molecular mass values in the $480 \mathrm{kDa}$ region and are constructed from polypeptides of around 34 and $45 \mathrm{kDa}$ (Bergh \& Evans, 1993;
Shepherdson \& McPhail, 1993; Schurr et al., 1995). It therefore seemed likely that bacterial ATCases from outside the pseudomonad group which have similar high molecular mass values would have the same structure. Purification of $A$. calcoaceticus ATCase was undertaken to test this presumption. The enzyme was purified 780 -fold (Table 3). SDS-PAGE on the purified protein showed the molecule to contain polypeptides of 44 and $36 \mathrm{kDa}$ (Fig. 3 ), thus confirming the similarity of this enzyme with the ATCases of the fluorescent pseudomonads.

\section{DISCUSSION}

Our findings, and those of others, on the distribution of the different classes of bacterial ATCase are summarized in Table 4. It shows clearly that class A ATCases (molecular mass $\sim 450 \mathrm{kDa}$ ) are not confined to the fluorescent pseudomonads, but appear to be much more widely distributed. Enzymes of this type are now known to be present in nine species (see Table 4). It may be useful to view these results in a phylogenetic context. Within the $\gamma$ subdivision of the Proteobacteria, Woese et al. (1985) have defined three subgroupings, $\gamma-1, \gamma-2$ and $\gamma-3$ on the basis of $16 \mathrm{~S}$ rRNA partial sequence comparisons. They have further sought to define clusters of closely related organisms within these groups. One such cluster in the $\gamma$ 3 group is the fluorescent pseudomonads, the acinetobacters, the xanthomonads, S. maltophilia and lysobacters. It might therefore be expected that ATCases from all these organisms would share the class A structure. This is almost certainly so for $A c$. calcoaceticus ATCase which shows strong similarity to the ATCases of the fluorescent pseudomonads, both in the molecular mass of the polypeptide chains composing the subunits, and in the molecular mass of the holoenzyme. Unexpectedly however, X. campestris, S. maltophilia and Lys. enzymogenes, had ATCases of approximately $100 \mathrm{kDa}$, suggesting that only the catalytic trimer was present. Purification of the $S$. maltophilia ATCase confirmed that only $35 \mathrm{kDa}$ polypeptide chains were present in the molecule. An explanation for this could be that the catalytic and non- 
Table 3. Purification of ATCase from Ac. calcoaceticus

\begin{tabular}{|lcccc|}
\hline Step & $\begin{array}{c}\text { Total } \\
\text { activity } \\
\text { (units) }\end{array}$ & $\begin{array}{c}\text { Specific } \\
\text { activity } \\
\text { [units } \\
\text { (mg } \\
\text { protein) }\end{array}$ & $\begin{array}{c}\text { Purification } \\
\text { factor } \\
\text { (-fold) }\end{array}$ & $\begin{array}{c}\text { Yield } \\
\text { (\%) }\end{array}$ \\
\hline $\begin{array}{l}\text { 1. Sonicate* } \\
\begin{array}{l}\text { 2. Anion exchange } \\
\text { (Mono Q) }\end{array}\end{array}$ & 40 & $0 \cdot 4$ & 1 & 100 \\
$\begin{array}{l}\text { 3. Hydrophobic interaction } \\
\text { chromatography (Phenyl }\end{array}$ & 18 & 37 & 92 & 55 \\
$\begin{array}{l}\text { Sepharose) } \\
\text { 4. Gel filtration }\end{array}$ & 8 & 197 & 492 & 45 \\
\hline
\end{tabular}

* Prepared from 11 of culture.

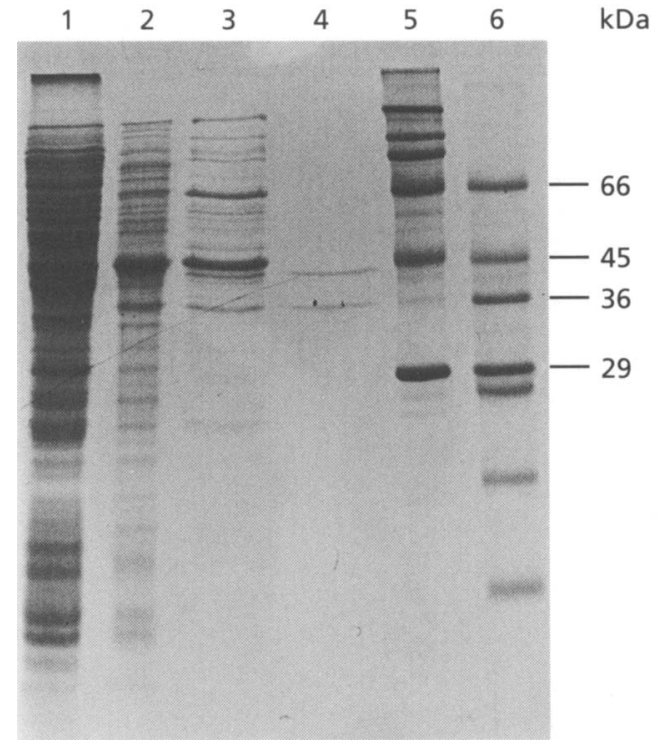

Fig. 3. SDS-PAGE of the stages in the purification of ATCase from Ac. calcoaceticus. Lanes: 1, sonicate; 2 , after anion exchange chromatography; 3, after Phenyl Sepharose chromatography; 4, the purified enzyme after gel filtration; 5 and 6, high- and lowmolecular-mass markers, respectively.

catalytic subunits dissociate very readily in these species, although we regard this as unlikely in view of the known stable binding of the two types of subunit in the fluorescent pseudomonads (Bergh \& Evans, 1993; Shepherdson \& McPhail, 1993). We have tried to exclude the possibility that the $100 \mathrm{kDa}$ enzymes identified in this study are dissociation products of class A or class B ATCases. We have not been able to detect the presence of class B non-catalytic subunits (genes or polypeptides) in $S$. maltophilia using Southern or Western blotting (results not shown). A similar approach to the class A enzymes is complicated by the homology of the $45 \mathrm{kDa}$ gene with the dihydroorotase gene (Schurr et al., 1995). In testing for the expression of the $45 \mathrm{kDa}$ subunit, we were handicapped by polyclonal antisera raised to Ac. calcoaceticus
ATCase proving to be very species-specific. A further indication that $S$. maltophilia ATCase has not dissociated during extraction is the observation that the molecular mass is unaltered under conditions designed to preserve the integrity of the enzyme.

Another possibility, which cannot be discounted, is that the $100 \mathrm{kDa}$ enzyme is the dissociation product of some hitherto unrecognized form of ATCase.

As far as we are aware, ATCases of the class $C$ type (molecular mass $\sim 100 \mathrm{kDa}$ ) have not previously been reported in any Gram-negative bacteria, although they seem to be the only type to have been observed in Grampositive bacteria (see Table 4).

From RNA/DNA hybridization studies, Azomonas agilis and Azotobacter vinelandii both appear to be related to Group 1 pseudomonads (DeSmedt et al., 1980). Evidence from Byng et al., (1986) based on the pattern of enzymes involved in aromatic biosynthesis, suggest that they are closest to Group 1a. We found both these organisms had class A ATCases. Interestingly, so did Para. denitrificans and $D$. radiophilus, the former species being from the $\alpha$ subgroup of the Proteobacteria, and the latter, being phylogenetically distant from the Proteobacteria (Woese, 1987).

The enterobacters, vibrios and photobacteria form another well-defined grouping within the $\gamma$-3 subgroup (Woese et al., 1985). Wild et al. (1980) have determined the molecular mass of many ATCases from the Enterobacteriaceae, and found all of them to be of the class B (molecular mass $\sim 300 \mathrm{kDa}$ ) variety, typified by E. coli ATCase. We have found $V$. natriegens ATCase to be of the same type.

From the present state of evidence, it seems that class B ATCases may be confined to the enteric bacteria and their close relatives. The comparatively widespread distribution of class A ATCases, in contrast to the apparently restricted distribution of class B ATCases, makes it tempting to consider the possibility that the ATCases of the type found in the enterobacteria and their relatives, are an offshoot from the main evolutionary pathway and that those on the main pathway are the class A type. 
Table 4. Distribution of the three classes of bacterial ATCase

\begin{tabular}{|c|c|c|c|c|}
\hline Organism & $\begin{array}{c}\text { Class A } \\
(\sim 450 \mathrm{kDa})^{*}\end{array}$ & $\begin{array}{c}\text { Class B } \\
(\sim 300 \mathrm{kDa})^{*}\end{array}$ & $\begin{array}{c}\text { Class C } \\
(\sim 100 \mathrm{kDa})^{*}\end{array}$ & $\begin{array}{c}\text { Source/ } \\
\text { reference } \dagger\end{array}$ \\
\hline \multicolumn{5}{|l|}{ Gram-negative } \\
\hline Aeromonas bydrophila $\ddagger$ & & + & & (1) \\
\hline Citrobacter diversus $\ddagger$ & & + & & (1) \\
\hline Enterobacter aerogenes $\ddagger$ & & + & & (1) \\
\hline Enterobacter (Serratia) liquifaciens $\ddagger$ & & + & & (1) \\
\hline Erwinia carnegieana $\ddagger$ & & + & & (1) \\
\hline Erwinia berbicola $\ddagger$ & & + & & $(1)$ \\
\hline Escherichia coli & & + & & $(1,2)$ \\
\hline Proteus vulgaris $\ddagger$ & & + & & $(1)$ \\
\hline Salmonella typhimurium $\ddagger$ & & + & & (1) \\
\hline Serratia marcescens $\ddagger$ & & + & & (1) \\
\hline Sbigella flexneri† & & + & & (1) \\
\hline Yersinia enterocolitica $\ddagger$ & & + & & (1) \\
\hline Vibrio natriegens $\ddagger$ & & + & & (2) \\
\hline Pseudomonas fluorescens $\leqq$ & + & & & (3) \\
\hline Pseudomonas syringae $\|$ & + & & & (2) \\
\hline Pseudomonas putida & + & & & (4) \\
\hline Acinetobacter calcoaceticus $\|$ & + & & & (2) \\
\hline Azomonas agilis** & + & & & (2) \\
\hline Azotobacter vinelandii** & + & & & (2) \\
\hline Leucotbrix mucor** & + & & & (2) \\
\hline Paracoccus denitrificans** & + & & & (2) \\
\hline Deinococcus radiophilus $\|+\dagger$ & + & & & (2) \\
\hline Stenotrophomonas maltophilial & & & + & (2) \\
\hline Xanthomonas campestris\| & & & + & (2) \\
\hline Lysobacter enzymogenes\|" & & & + & (2) \\
\hline \multicolumn{5}{|l|}{ Gram-positive } \\
\hline Bacillus subtilis $\ddagger$ & & & + & (5) \\
\hline Streptococcus faecalis $\ddagger$ & & & + & (6) \\
\hline Stapbylococcus epidermidis $\ddagger$ & & & + & (7) \\
\hline
\end{tabular}

* +, ATCase activity corresponds with this molecular mass (smaller molecular mass forms have sometimes been observed in addition to those reported here but these account for only a small percentage of the total activity).

$\dagger 1$, Wild et al. (1980); 2, this investigation; 3, Bergh et al. (1993); 4, Schurr et al. (1995); 5, Brabson \& Switzer (1975); 6, Chang et al. (1974); 7, M. Shepherdson, unpublished.

$\ddagger$ Obtained by gel filtration.

$\$$ Obtained by gel filtration and sucrose density gradient centrifugation.

\| Obtained by gel filtration and gradient electrophoresis.

g Obtained by gradient electrophoresis and from the derived amino acid sequence of the cloned gene.

** Obtained by gradient gel electrophoresis.

†† Despite staining Gram-positive, Deinococcaceae are thought to be more closely allied to the Gramnegative bacteria (Murray, 1986).

The ATCase from Leu. mucor, which proved to be of the class A type, is interesting in that according to Woese et al. (1985), this species is peripherally related to the enterics and vibrios, and so may be near the bifurcation point dividing species possessing the class $\mathrm{A}$ and class $\mathrm{B}$ enzymes.

So far we have not considered the functional importance of the two types of non-catalytic subunit and their genetic origins. The most extensively studied ATCase of the class
B type is from E. coli. In this enzyme there is no doubt that the non-catalytic subunit plays an extremely important part in the allosteric regulation of enzyme activity [although this is less clear for other enterobacteria (Foltermann et al., 1981)]. Possibly the need for highly effective regulation was the driving force for the acquisition of this subunit. If so, what was its genetic origin? Did it appear as the result of duplication of the gene for a nucleotide-binding protein serving some other function? 
The situation with regard to the function and genetic origin of the larger non-catalytic subunit may turn out to be more comprehensible, at least in broad concept. Schurr et al. (1995) have shown that the non-catalytic $44 \cdot 2 \mathrm{kDa}$ polypeptide chains in Ps. putida ATCase are homologous with the next enzyme in the pathway, dihydroorotase, although it does not itself possess dihydroorotase activity. Presumably this polypeptide has arisen as a result of gene duplication. It is not clear what functional role, if any, these six polypeptide chains play. From an evolutionary point of view, the association of the catalytic subunit together with a dihydroorotase homologue may be significant since, in eukaryotic cells, gene fusion has given rise to multifunctional enzymes, e.g. the CAD protein in mammals in which the first three enzyme activities in the biosynthetic pathway are all present on the same polypeptide. This has led Schurr et al. (1995) to suggest that class A enzymes may be a vestige of the eukaryotic CAD complex (reviewed by Davidson et al., 1993) or its progenitor (Schurr et al., 1995); the latter may be more probable.

A closer link in the evolutionary relationship between the bacterial and higher eukaryote ATCases may be the yeast UR $A 2$ gene (Souciet et al., 1989). This gene encodes a multifunctional protein which has both carbamoyl phosphate synthetase and ATCase activities. Situated between these two genes is a domain encoding a non-functional dihydroorotase which is homologous with the CAD dihydroorotase, although not with its monofunctional counterparts in bacteria and yeast.

While preparing this manuscript we have seen a preliminary communication reporting similar findings and conclusions (O’Donovan \& Shanley, 1995).

\section{REFERENCES}

Arcus, A. C. (1970). Protein analysis by electrophoretic molecular sieving in a gel of graded porosity. Anal Biochem 37, 53-63.

Bergh, S.T. \& Evans, D. E. (1993). Subunit structure of class A aspartate transcarbamoylase from Pseudomonas fuorescens. Proc Natl Acad Sci US A 90, 9819-9822.

Bethell, M. R. \& Jones, M. E. (1969). Molecular size and feedbackregulation characteristics of bacterial aspartate transcarbamylases. Arch Biochem Biophys 134, 352-365.

Brabson, J. S. \& Switzer, R. L. (1975). Purification and properties of Bacillus subtilis aspartate transcarbamylase. J Biol Chem 250, 86648669.

Bradford, M. M. (1976). A rapid and sensitive method for the quantitation of microgram quantities of proteins utilizing the principle of protein-dye binding. Anal Biochem 72, 248-254.

Byng, G. S., Berry, A. \& Jensen, R. A. (1986). Evolution of aromatic biosynthesis and functional phylogenetic positioning of Azomonas, Azotobacter and rRNA group I pseudomonads. Arch Microbiol 144, 222-227.

Chang, T.-Y. (1974). Aspartate transcarbamoylase from Streptococcus faecalis. Purification, properties and nature of an allosteric activator site. Biochemistry 13, 629-638.

Davidson, J. N., Chen, C. C., Jamison, R. S., Musmanno, L. A. \& Kern, C. B. (1993). The evolutionary history of the first three enzymes in pyrimidine biosynthesis. BioEssays 15, 157-164.
DeSmedt, J., Bauwens, M., Tygat, R. \& Deley, J. (1980). Intra- and intergenic similarities of ribosomal ribonucleic acid cistrons of freeliving nitrogen-fixing bacteria. Int J Syst Bacteriol 30, 106-112.

Foltermann, K. F., Wild, J. R., Zink, D. L. \& O’Donovan, G. A. (1981). Regulatory variance of aspartate transcarbamoylase among strains of Yersinia enterocolitica and Yersinia enterocolitica-like organisms. Curr Microbiol 6, 43-47.

Gerhart, J. C. \& Holoubek, H. (1967). The purification of aspartate transcarbamylase of Escherichia coli and separation of its protein subunits. J Biol Chem 242, 2886-2892.

Grayson, J. E., Yon, R. J. \& Butterworth, P. J. (1979). Wheat germ aspartate transcarbamylase. Purification and cold lability. Biochem $J$ 183, 239-245.

Kantrowitz, E. R. \& Lipscomb, W. N. (1990). Escherichia coli aspartate transcarbamoylase: the molecular basis for a concerted allosteric transition. Trends Biochem Sci 15, 53-59.

Ke, H.-M., Honzatco, R. B. \& Lipscomb, W. N. (1984). Structure of the unligated aspartate carbamoyl transferase of Escherichia coli at $2.6 \AA$ resolution. Proc Natl Acad Sci US A 81, 4037-4040.

Laemmli, U. K. (1970). Cleavage of structural proteins during the assembly of the head of bacteriophage T4. Nature 227, 680-685.

Murray, R. G. E. (1986). Deinococcaceae Brookes and Murray 1981, $356^{\mathrm{VP}}$. In Bergey's Manual of Systematic Bacteriology, Vol. 2, pp. 1035-1043. Edited by P. H. A. Sneath, N. S. Mair, M. E. Sharpe \& J. G. Holt. Baltimore: Williams \& Wilkins.

O'Donovan, G. A. \& Shanley, M. (1995). Pyrimidine metabolism in Pseudomonas. Paths to Pyrimidines: An International Newsletter 3, 49-59.

Robey, E. A. \& Schachman, H. K. (1985). Regeneration of active enzyme by formation of hybrids from inactive derivatives: implications for active sites shared between polypeptide chains of aspartate transcarbamylase. Proc Natl Acad Sci US A 82, 361-365.

Schurr, M. J., Vickrey, J. F., Kumar, A. P., Campbell, A. L., Cunin, R., Benjamin, R. C., Shanley, M. S. \& O'Donovan, G. A. (1995). Aspartate transcarbamoylase genes from Pseudomonas putida: requirement for an inactive dihydro-orotase for assembly into the dodecameric holoenzyme. J Bacteriol 177, 1751-1759.

Shepherdson, M. \& McPhail, D. (1993). Purification of aspartate transcarbamoylase from Pseudomonas syringae. FEMS Microbiol Lett 114, 201-206.

Souciet, J. L., Nagy, M., Le Gouar, M., Lacroute, F. \& Potier, S. (1989). Organisation of the $U R A 2$ gene: identification of a defective dihydroorotase-like domain in the multifunctional carbamoyl phosphate synthetase-aspartate transcarbamoylase complex. Gene 79, 59-70.

Switzer, R. L. \& Quinn, C. L. (1993). De novo pyrimidine nucleotide synthesis. In Bacillus subtilis and Otber Gram-positive Bacteria, pp. 343-358. Edited by A. L. Sonenshein, J. A. Hoch \& R. Losick. Washington, DC: American Society for Microbiology.

Wild, J. R., Foltermann, K. J. \& O'Donovan, G. A. (1980). Regulatory divergence of aspartate transcarbamoylases within the Enterobacteriaceae. Arch Biocbem Biopbys 201, 506-517.

Woese, C. R., Weisburg, W. G., Hahn, C. M., Paster, B. J., Zablen, L. B., Lewis, B. J., Macke, T. J., Ludwig, W. \& Stackebrandt, E. (1985). The phylogeny of purple bacteria: the gamma subdivision. Syst Appl Microbiol 6, 25-33.

Woese, C. R. (1987). Bacterial evolution. Microbiol Rev 51, 221-271.

Received 24 November 1995; revised 9 February 1996; accepted 23 February 1996. 